\title{
A Review on Interesting Properties of Chicken Feather as Low-Cost Adsorbent
}

\author{
Wei Chek Moon', Puganeshwary Palaniandy ${ }^{1, *}$
}

${ }^{1}$ School of Civil Engineering, Engineering Campus,
Universiti Sains Malaysia, 14300 Pulau Pinang, MALAYSIA

*Corresponding Author

DOI: https://doi.org/10.30880/ijie.2019.11.01.015

Received 13 June 2018; Accepted 26 September 2018; Available online 10 May 2019

\begin{abstract}
Adsorption process has been used widely in the treatments related to environmental issues due to its modestness and ease of operation. Through the years, the development of low-cost absorbents has been given much attention in the adsorption process. The applications of chicken feather, a byproduct in poultry farming on wastewater treatment are boon for the worldwide researchers. In this review paper, the possible mechanism of adsorption, the adsorption isotherms and the factors affecting the adsorption process are first discussed. Next, this paper provides a review on the potential low-cost adsorbent of chicken feather: its composition, morphological structure and properties. This paper also describes the preparation of chicken feather as an adsorbent with different activation methods. The unique morphological structure of chicken feather enhances its interesting properties for several types of applications purposes. Lastly, the applications of chicken feather proved by the past studies are presented in this paper.
\end{abstract}

Keywords: Adsorption, Langmuir, Freundlich, chicken feather

\section{Introduction}

In the modern era of globalization, the increase of population in our world has increased the risk of environmental pollution. The main sources of environmental pollution are the industrial and agricultural activities. The rapid industrialization of human society produces different contaminants or pollutants in wastewater that may release to the environment and create a major global concern nowadays [1]. Heavy metals are the alarming pollutants in the industrial effluents due to their non-destructive nature, toxicity, bioaccumulation and subsequent biomagnifications [2]. Heavy metals such as arsenic, cobalt, copper, iron, mercury, lead and zinc are the most commonly encountered metals in the industrial wastewater from mining, battery and chemical manufacturing industries [1]. In fact, heavy metals are the essential trace elements for living creatures in the world including human, animals and plants. However, large amounts of heavy metals may lead to acute and toxicity.

Besides, the discharge of coloured effluents from the textile dyeing industry is one of the major causes of water pollution today [3]. The water colour is an apparent indicator of water pollution due to the presence of dyes. Dyes which are the most problematic pollutants can be grouped into several structural varieties such as acidic, basic, azo, diazo, disperse, anthraquinone based as well as metal complex dyes. Apart from that, another environmental challenge is the production and storage of hydrogen gas $\left(\mathrm{H}_{2}\right)$. In future, an $\mathrm{H}_{2}$ economy based on renewable energy is expected to have a significant impact on the energy distribution [4]. This is because $\mathrm{H}_{2}$ is not available as individual elements in the atmosphere and it is the lightest gas in the world, thus it is not held by the earth's gravity.

Being the utmost importance of environment towards living creatures in the world, the demand of its quality rehabilitation and preservation are the major concerns of this century. Literature reports that the adsorption process is one of the widely used methods to deal with the wastewater treatment. Adsorption is advantageous, especially when the metal concentrations range from $1 \mathrm{mg} / \mathrm{L}$ to $100 \mathrm{mg} / \mathrm{L} \mathrm{[5].} \mathrm{There} \mathrm{are} \mathrm{many} \mathrm{absorbents} \mathrm{used} \mathrm{nowadays} \mathrm{which} \mathrm{are}$ 
generated from different sources of materials such as household wastes, agricultural products, industrial wastes, sea materials, soil and ore materials [6]. In the past, there are four types of generic adsorbents dominating the commercial use of adsorbents which are activated carbon, activated alumina, silica gel and zeolites [7]. However, these adsorbents are economically not efficient, thus cannot be used in a large scale. Therefore, the development of low-cost absorbents had been an attempt for the researchers. They had searched for the new way about cheap precursor as absorbent by reducing the cost of raw materials. In the development of low-cost adsorbents, the selection of the precursor depends upon several factors especially inexpensive, high availability, and non-hazardous in nature. The types of these precursors can be divided into organic and inorganic [6].

\section{Adsorption as Water and Wastewater Treatment Option}

Adsorption is a surface phenomenon that takes place when a gas or liquid solute is adhered onto an adsorbent's surface, forming a film of adsorbate. An adsorbate is any substance which is removed from its gas or liquid phase at the interface. The term sorption encompasses both processes of adsorption and desorption which is the reverse of adsorption. Due to the development of the sorbent and cyclic process, adsorption has been developed as a key separations tool in industries especially the chemical industry [7]. This technique has been well-established and widely used for the industrial effluent treatment of a variety of water pollutants. For instance, adsorption approach has been adopted by Wang et al. [8] in the treatment of heavy metals by using graphene oxide-based silica materials. Activated carbon synthesized from apricot stones was applied by Djilani et al. [9] for the removal of Methyl Orange via adsorption process. Similar technique has been used for the removal of a variety of pesticides in the study of Ruggieri et al. [10]. Besides this, adsorption study was also conducted by researchers using different kind of absorbents in wastewater treatment of pharmaceuticals products [11].

In the past, activated carbon, activated alumina, silica gel and zeolites have been subjugated the commercial use of adsorption, due to their high degree of porosity [12]. The worldwide commercial demand for these adsorbent materials in 2001 is shown in Table 1.

Table 1 Commercial demand for adsorbent materials in 2001 [7]

\begin{tabular}{cc}
\hline Adsorbent & $\begin{array}{c}\text { Commercial Demand } \\
\text { (USD) }\end{array}$ \\
\hline Activated carbon & 1 billion \\
Zeolites & 100 billion \\
Silica gel & 27 billion \\
Activated alumina & 26 billion \\
\hline
\end{tabular}

Adsorption acts as a separation process which means an involuntary process and an exothermic process that liberates energy. Thus, it is costly due to the need of chemicals, energy and the separation agent or sorbent. The surface of the adsorbent and the pore size of adsorbate molecule are playing the important role in determining the effectiveness of the adsorption process. Besides, a minimum amount of energy should be supplied to provide a good contact between the liquid and the surface of adsorbent under certain conditions to obtain the equilibrium state, thus encouraging or limiting the diffusion limitations [7].

The adsorption process consists of four steps as shown in Fig. 1. The first step will be the bulk solution transport. This step involves the movement of the substance to be adsorbed through the bulk liquid to an extremely thin surface layer of the adsorbent. This is followed by the second step, film diffusion transport, whereby the substance is diffused to the entrance of the pore of adsorbent through the stagnant liquid film. In the third step, pore transport will occur. In this step, the substance will be adsorbed through the pores and along the surface of the adsorbent. Lastly, the forth step will be the adsorption in which the adsorbate adheres to the surface of the adsorbent at an available adsorption site [13].

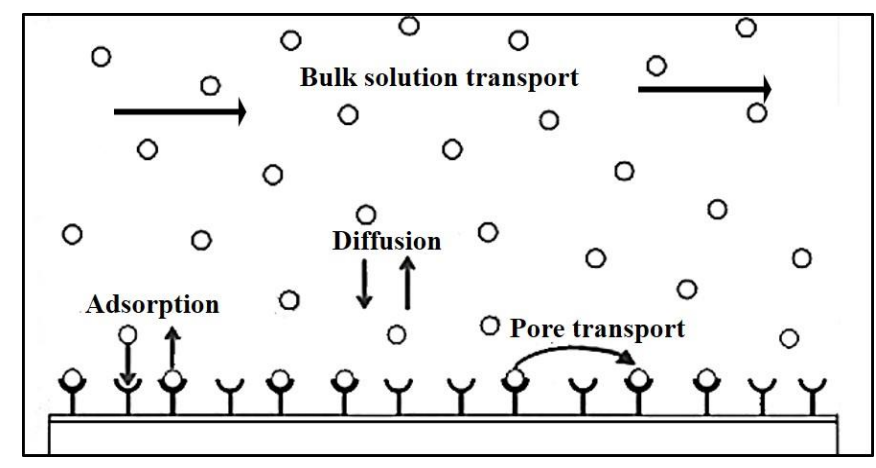

Fig. 1 - Schematic diagram of adsorption process 


\subsection{Mechanism of Adsorption}

The term adsorption can be described by two kinds of adsorption mechanisms: chemisorption (chemical adsorption) and physisorption (physical adsorption). Chemisorption is a type of adsorption whereby the attraction between the adsorbent and adsorbate through the formation of a chemical bond with shorter bond length, resulting in releasing energy which is known as an exothermic process. This type of adsorption involves high adsorption energy which is higher than $1 \mathrm{eV}$ per adsorbent molecule. Therefore, desorption is impossible or may need a high amount of energy to reverse the process for recycling the adsorbent.

As for physisorption, it is the second type of adsorption whereby the attraction between the adsorbent and adsorbate through the Van der Waals interactions. Physisorption is industrially favored due to the low adsorption energy which is lower than $1 \mathrm{eV}$ per adsorbent molecule, thus requiring shorter time than that of the chemisorptions. In addition, the simplicity of the desorption process will be enhanced [14]. The adsorption process is usually controlled by physical forces (Van der Waals forces, hydrogen bonds, hydrophobicity, polarity and steric interaction, dipole induced dipole interaction) [6], with some exception of chemisorptions. The differences of physisorption and chemisorptions are summarized in Table 2.

Table 2 - Properties of physisorption and chemisorptions [36]

\begin{tabular}{ll}
\hline \multicolumn{1}{c}{ Physisorption } & \multicolumn{1}{c}{ Chemisorption } \\
\hline - Multilayer adsorption & Monolayer adsorption \\
- Low degree of specificity & $\begin{array}{l}\text { Depends on the reactivity of adsorbent and adsorbate } \\
\text { substance }\end{array}$ \\
$\begin{array}{ll}\text { - Desorption is possible as adsorbed molecule keep } \\
\text { its identity }\end{array}$ & $\begin{array}{l}\text { Desorption is impossible as adsorbed molecule loses its } \\
\text { identity } \\
\text { - Exothermic }\end{array}$ \\
$\begin{array}{l}\text { - Exothermic or endothermic } \\
\text { rapidly rem reaches thermodynamic equilibrium }\end{array}$ & $\begin{array}{l}\text { - Activation energy is involved and system may not reach } \\
\text { equilibrium }\end{array}$ \\
\hline
\end{tabular}

\subsection{Adsorption Isotherms}

Adsorption is also described via isotherms. The relation between the quantity of adsorbate on the adsorbent and the concentration is known as the adsorption isotherm which can be described by the following equation. There are two conditions to be met: (i) the various reaction equilibrium of retention is reached, and (ii) all the physic-chemical parameters are constant. The word "isotherm" is related to the effect of the temperature on the sorption reaction where the temperature remains constant [15].

In the previous work by Limousin and his co-researchers [16], it states that when the retention of a solute on solid particles is investigated, the remaining solute concentration of the compound $C(\mathrm{~mol} / \mathrm{L} \mathrm{or} \mathrm{kg} / \mathrm{L})$ can be compared with the concentration of this compound retained on solid particles $Q(\mathrm{~mol} / \mathrm{kg}$ or $\mathrm{kg} / \mathrm{kg})$. In Fig. 2, the concentration of the compound retained on solid particles $Q$ is calculated by the difference between the initial solute concentration $\left(C_{a o}\right.$ or $\left.C_{b o}\right)$ and the final solute concentration $C$ only if the initial solid concentration $\left(Q_{a o}\right.$ or $\left.Q_{b o}\right)$ is negligible or previously measured [12].

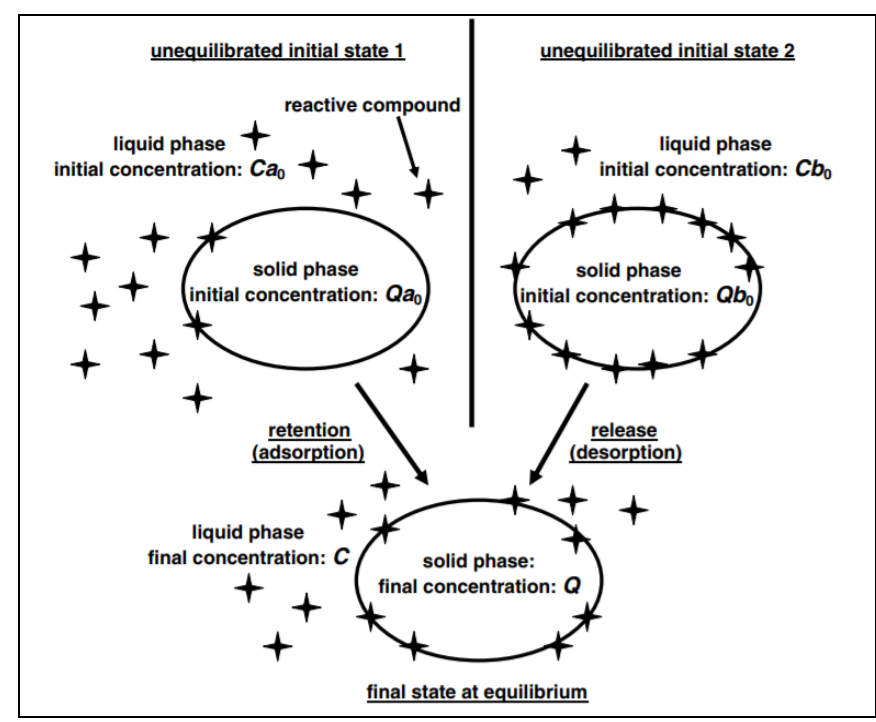

Fig. 2 - Schematic views of the adsorption and desorption phenomena [16] 
In the retention stage, the solid concentration at equilibrium $Q(\mathrm{~mol} / \mathrm{kg})$ is defined in Eq. (1), where $V$ is volume of solution $(\mathrm{L}), m$ is solid mass $(\mathrm{g}), C_{a o}$ is initial solute concentration $(\mathrm{mol} / \mathrm{L}), C$ is final solute concentration $(\mathrm{mol} / \mathrm{L})$ and $Q_{a o}$ is concentration of the compound initially retained on the solid ( $\left.\mathrm{mol} / \mathrm{kg}\right)$.

$$
Q=\frac{V}{m}\left(C_{a o}-C\right)+Q_{a o}
$$

For the case of a release stage of a compound which is initially retained on the solid phase, the quantity of this initially retained compound $Q_{b o}$ must be measured in advance. Then, the solid concentration at equilibrium can be calculated using equation (1), replacing $C_{a o}$ by $C_{b o}$ and $Q_{a o}$ by $Q_{b o}$ [16].

Adsorption isotherm is important in explaining how solutes interact with adsorbents, thus optimizing the use of adsorbents. In the current development, various types of isotherm models have been developed to describe the process of adsorption. Langmuir and Freundlich isotherms are the two common adsorption isotherms used to explain the equilibrium characteristics of adsorption [17].

\subsubsection{Langmuir Isotherm}

The Langmuir isotherm model is based on a few assumptions: (i) the maximum adsorption occurs when there is a saturated monolayer of solute molecules exist on the surface of the adsorbent, (ii) the energy of adsorption on the surface is uniform, and (iii) there is no transfer of adsorbate molecules in the surface plane [18].

Langmuir isotherm is applied well to physical and chemical adsorption when saturation is reached. The linear form of Langmuir isotherm is defined as:

$$
\frac{C_{e}}{q_{e}}=\frac{1}{b Q_{o}}+\frac{C_{e}}{Q_{o}}
$$

where: $C_{e}$ is equilibrium concentration of adsorbate $(\mathrm{mg} / \mathrm{L}), q_{e}$ is amount of adsorbate adsorbed per unit mass of adsorbent (mg/g), $Q_{o}$ is empirical Langmuir constant (related to maximum adsorption capacity), and $b$ is empirical Langmuir constant (related to rate of adsorption).

\subsubsection{Freundlich isotherm}

The Freundlich isotherm model is an empirical equation for describing the physical adsorption of solutes from liquid to solid surface. There is a multilayer adsorption and there is no limit to the amount adsorbed. In the case of heterogeneous surface energies, Freundlich isotherm is better for adsorption isotherm which is defined as:

$$
q_{e}=K_{F} C_{e}^{1 / n}
$$

where: $q_{e}$ is amount of adsorbate adsorbed per unit mass of adsorbent $(\mathrm{mg} / \mathrm{g}), K_{F}$ is empirical Freundlich constant or capacity factor $(\mathrm{mg} / \mathrm{g}), C_{e}$ is the equilibrium concentration of adsorbate $(\mathrm{mg} / \mathrm{L}), 1 / n$ is Freundlich intensity parameter. $1 / n$ is an index of diversity of free energies related to the adsorption of the solutes by multiple components of a heterogeneous adsorbent. When the value is approaching 1, the isotherm is linear and the system has a constant free energy at all adsorbate concentrations. As for a value below 1, it indicates a normal Freundlich isotherm whereby the cooperative adsorption occurs if the value of $1 / n$ is more than 1 [19]. The constants can be determined by plotting log $q_{e}$ against $\log C_{e}$ which is shown below.

$$
\log q_{e}=\log K_{F}+\frac{1}{n} C_{e}
$$

\subsection{Factors Affecting Adsorption Process}

The process of adsorption is affected by several factors such as the internal surface area of adsorbent, $\mathrm{pH}$, the mass of adsorbent, the initial concentration of adsorbate and temperature. As the adsorption process takes place on the surface of the adsorbent, thus its pores size on the surface is playing an important role. At a given temperature (below $30{ }^{\circ} \mathrm{C}$ ), the efficiency of adsorption increases with the increase of the internal surface area of adsorbent [6]. Another important factor includes the $\mathrm{pH}$ value of the solution. The $\mathrm{pH}$ causes the ionization of active sites, hence affecting the removal performance. As the value of $\mathrm{pH}$ is below 3, there will be a little sorption due to the carboxylic sites are mainly protonated, thus causing less sites for the adsorption process. As $\mathrm{pH}$ increases, the efficiency of adsorption increases due to the deprotonation, thus increasing the negative charge density on the sorbent surface [20]. 
In addition, the mass of adsorbent and the initial concentration of adsorbate might affect the efficiency of the adsorption process too. As the mass of adsorbent increases, the efficiency of adsorption increases [21]. Besides, the adsorption efficiency also increases with the initial concentration of the adsorbate [22]. Adsorption process may also be affected by the temperature changes during the adsorption process. As the temperature increases (below $30{ }^{\circ} \mathrm{C}$ ) causes the stretching of adsorbent, thus there will be more active site for the adsorption process [20].

Table 3 - Removal of heavy metals by using different forms of keratin material made from chicken feathers

\begin{tabular}{|c|c|c|c|c|}
\hline $\begin{array}{l}\text { Heavy } \\
\text { Metal }\end{array}$ & $\begin{array}{c}\text { Initial Conc. of } \\
\text { Heavy Metal } \\
(\mathrm{mg} / \mathrm{L})\end{array}$ & $\begin{array}{c}\text { Removal } \\
\text { Percentage } \\
(\%)\end{array}$ & Modification of Chicken Feather & Ref \\
\hline $\mathrm{Cu}$ & $10-100$ & 75.0 & \multirow{2}{*}{$\begin{array}{l}\text { Chicken feather particle treated with } \mathrm{NaOH} \text { and } \\
\text { dodecyl sulphate }\end{array}$} & \multirow[t]{2}{*}[22]{} \\
\hline $\mathrm{Zn}$ & $10-100$ & 31.3 & & \\
\hline $\mathrm{Cu}$ & $10-40$ & 48.8 & \multirow[t]{6}{*}{ Ultrasonic processing } & \multirow[t]{6}{*}[39]{} \\
\hline $\mathrm{Pb}$ & $10-40$ & 83.5 & & \\
\hline $\mathrm{Hg}$ & $10-40$ & 97.6 & & \\
\hline $\mathrm{Zn}$ & $10-40$ & 3.8 & & \\
\hline $\mathrm{Cd}$ & $10-40$ & 17.0 & & \\
\hline $\mathrm{Ni}$ & $10-40$ & 10.1 & & \\
\hline $\mathrm{Ca}$ & $50-1000$ & $72-94$ & \multirow[t]{4}{*}{ Keratin amino acid immobilized silica particle } & \multirow[t]{4}{*}[21]{} \\
\hline $\mathrm{Fe}$ & & & & \\
\hline $\mathrm{Mg}$ & & & & \\
\hline $\mathrm{Mn}$ & & & & \\
\hline $\mathrm{Pb}$ & $10-200$ & 83.0 & Acidic treatment with addition of ethanol & [20] \\
\hline $\mathrm{Cr}$ & $10-80$ & 90.0 & \multirow{2}{*}{$\begin{array}{l}\text { Alkaline treatment with addition of epichlorohydrin } \\
\text { and ethylenediamine }\end{array}$} & \multirow[t]{2}{*}{ [40] } \\
\hline $\mathrm{Cu}$ & $10-80$ & 7.5 & & \\
\hline $\mathrm{Cr}^{6+}$ & $10-80$ & 90 & $\begin{array}{l}\text { Chicken feather treated with epichlorohydrin } \\
\text { and ethylenediamine }\end{array}$ & [41] \\
\hline $\mathrm{Cr}$ & 100 & 38.0 & $\begin{array}{l}\text { Hybrid polyurethane membrane with } 15 \text { weight } \\
\text { percent of chicken keratin (resin and fiber) }\end{array}$ & [42] \\
\hline
\end{tabular}

\section{Chicken Feather as Adsorbent}

There are many types of adsorbents that had been used in the world. The effectiveness of an adsorbent can be explained in term of the adsorption capacity, adsorption rate as well as the possibility of regeneration [7]. Recent studies so far have reported that the fibrous proteins contained in some wastes from the animal processing industry can be used as the sorbents for wastewater treatment [5]. Chicken feather is one of the main byproducts in poultry farming which is produced in a significant amount with no investment. However, most of the chicken feathers are treated as waste products [23], [24]. People used to dispose the waste product of chicken feather by incineration and underground burial.

In fact, the chicken feather is a potential low-cost adsorbent since the worldwide poultry consumption has generated a huge amount of chicken feather annually. Due to its interesting properties and its high availability as environmental waste, researchers have used it in many applications. Results have proven that the chicken feather fiber effectively removes several pollutants from the aqueous solutions, especially the heavy metals [5]. Table 3 shows the removal of heavy metals by using different forms of keratin material made from the chicken feathers. As for the removal of some colorants and the organic toxic compounds, the chicken feathers are also found to achieve satisfactory results for the sorption purpose [20].

\subsection{Chicken Feather Composition and Morphological Structure}

Chicken feathers act as a protective covering for chicken from outside weather and physical objects. Chicken feathers which occupied around $8.5 \%$ of the total mass are composed of approximately $91 \%$ keratin, $8 \%$ water and $1 \%$ lipids [25]. A feather has a protein content of about $84 \%$ along with the inorganic constituents (calcium, magnesium, selenium, zinc and others). However, the strong disulfide bonding of the amino acids as well as the high keratin content, make the raw feathers to have a very low digestibility of around 5\% and become relatively insoluble [3].

Unlike any other natural or synthetic fibers, chicken feathers have a unique structure. A feather is made up of two parts, namely the fibers and the quill. In fact, a feather mainly consists of three distinct units (Fig. 3). The rachis which is the central shaft of the feather attaches the barbs and the barbules which are the secondary and tertiary structures of the feather [26]. The barbs and the barbules are known as the chicken feather fibers (CFF), where the fiber diameters are found to be in the range of 5-50 $\mathrm{m}$ [25]. As for the feather rachis, it is stiff and thick, thus it is not suitable as a natural protein fiber. 


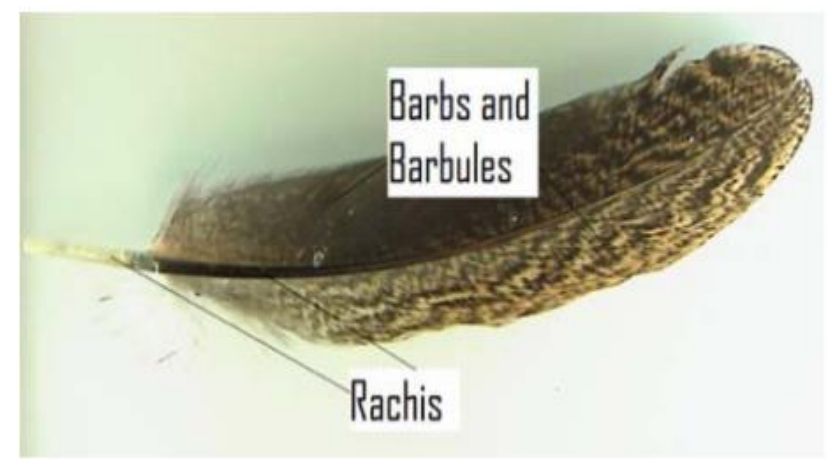

Fig. 3 - Three structural levels of the feather [26]

Fig. 4 and Fig. 5 respectively show the scanning electron microscope (SEM) of the tertiary structure of feathers and the cross-section of a barb, showing the hollow honeycomb shaped hollow cells. The barbules have lengths of around $0.3-0.5 \mathrm{~mm}$ and have hooks at their ends [26]. The feather barbs are more flexible than the rachis and able to twist as well as bend even when groups of barbs are together. The features of the flexibility, length and strength make the feather barbs suitable as the natural protein fibers. Moreover, the unique cross-section of barbs as shown in Fig. 5 is not found in any natural protein fibers such as silk, wool and others [26].

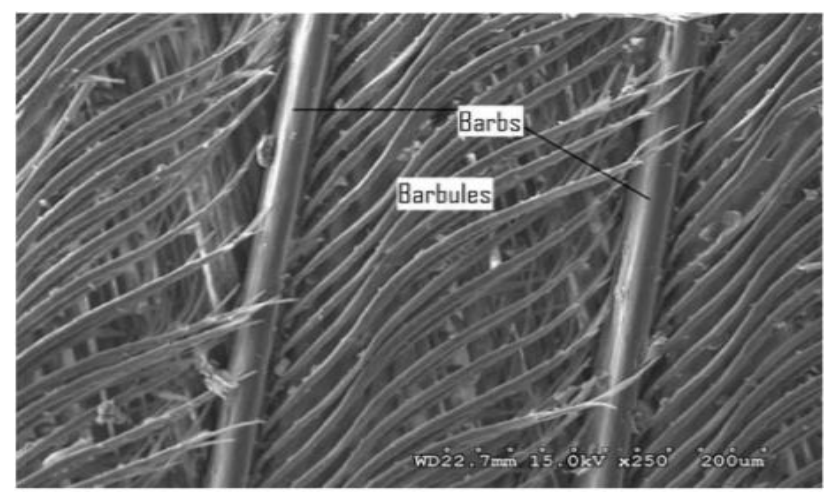

Fig. 4 - Tertiary structure of feathers [26]

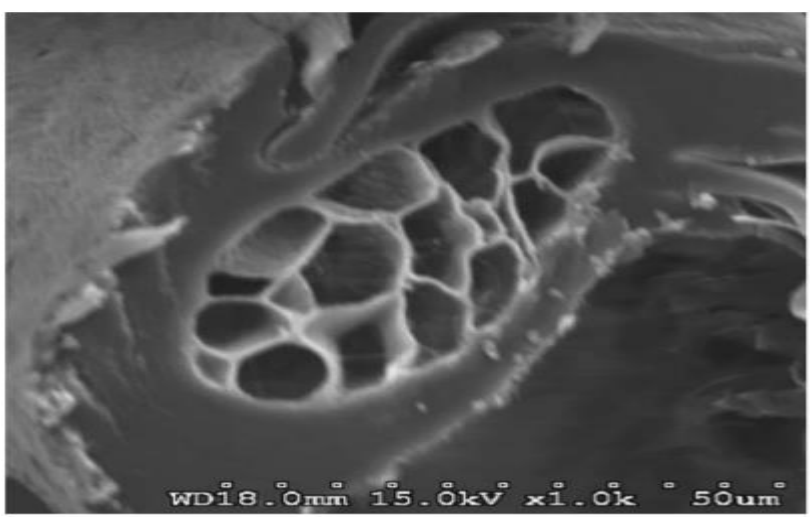

Fig. 5 - Hollow honeycomb shaped hollow cells in a barb [26]

\subsection{Chicken Feather Properties}

Chicken feathers have many interesting properties which had been explored and revealed by the other researchers and has a potential to be a good precursor for many application [26]. The main component of the chicken feather is keratin, a protein that possesses the unique physicochemical properties for the sorption process of metallic species [5]. The biomolecules of amino acids act as reactive sites of having a natural affinity towards metals, organic compounds 
and gases. Additionally, keratin is playing an important role in the enhancement of the advantages of chicken feathers. It had improved the tensile strength, structural toughness, water insolubility and stability over a wide range of $\mathrm{pH}$ [20].

Besides, $\alpha$-helix keratin is the formation of fiber' backbone from the flexible and long fiber, which is attributed to mimic the amino acid sequence of $\alpha$-helix, while $\beta$-sheet keratin is the fiber that acts to fill the spaces between the $\alpha$ helix tubes. The structural toughness of the chicken feather is contributed to the hydrogen bonding between each segment of the amino acid chains [27]. The bio origin material like chicken feather also has a lower density of approximately $0.8 \mathrm{~g} / \mathrm{cm}^{3}$ than water due to the honeycomb-shaped in the barbs, resulting in light weight [28]. The cross-section of honeycomb-shaped hollow cells in the barb provides good air and thermal insulating properties and increases the resistance to compressibility as well [29]. Overall, the above-mentioned interesting properties such as the low density, excellent compressibility and resiliency of feather barbs had made them a unique fiber.

\subsection{Activation Methods}

Activation methods enhance the effectiveness of chicken feather as a potential adsorbent by providing them with high pore volume and microporosity as well as improving their surface area ranging from $100 \mathrm{~m}^{2} / \mathrm{g}$ to $200 \mathrm{~m}^{2} / \mathrm{g}$. These advantages are important for the adsorption or separation process, purification and the storage of liquids and gases [27]. There are two types of activation methods by thermal and chemical treatment of chicken feather fiber to enhance their structural changes for a better adsorption [27].

\subsubsection{Chemical Treatment}

The first method is the chemical treatment. Chemical treatment is used to enhance the chicken feather fiber as a potential low-cost adsorbent by modifying the reactive site to be more effective in the adsorption process. The barbs were pre-treated by hydrogen peroxide for $24 \mathrm{~h}$ and washed with a copious amount of distilled water to remove the adhering impurities in feathers, followed by a drying process for overnight [3]. Besides, another alternative procedure included a washing process of the chicken feather with detergent, subsequent by aqueous ethanol $(20 \%, \mathrm{v} / \mathrm{v})$ for removing the organic residues [5]. In addition, active amino acids of chicken feather towards the metal uptake were also provided through the alkaline treatment with $\mathrm{NaOCl}$ and $\mathrm{NaOH}$ solutions as well as the immobilization of silica on the surface [21]. Table 4 shows the preparation of chicken feathers by chemical treatment.

\subsubsection{Thermal Treatment}

The second method is the thermal treatment. The effect of pyrolysis on the chicken feathers is studied on the morphological changes include side-chain degradation [27]. Pyrolysis process is an irreversible reaction which occurs by the thermal treatment in the absence of oxygen [30]. In the previous research by Senoz and Wool [27], a two-step pyrolysis approach is established to enhance the porous nature of chicken feather fiber and convert its quality into high temperature resistive. In the pyrolysis, the first step is the heat treatment of chicken feather at $215{ }^{\circ} \mathrm{C}$ which is below the keratin melting point with the purpose to study the effect of an isothermal treatment, and provide the good structure and mechanical strength for the fibers. As for the second step of pyrolysis $\left(400-450{ }^{\circ} \mathrm{C}\right)$, this step is important to achieve a narrower pore distribution of the microporous material, which is less than $1 \mathrm{~nm}$ for the use of hydrogen adsorption [27].

Table 4 - Examples of preparation of chicken feathers by chemical treatment

\begin{tabular}{|c|c|c|c|}
\hline $\begin{array}{l}\text { Type of Chemical } \\
\text { Activation }\end{array}$ & Reagent & Pollutant & Ref. \\
\hline Acidic treatment & Hydrogen peroxide & Indigo Carmine & {$[3]$} \\
\hline Alkaline treatment & $\begin{array}{l}\text { Sodium dodecylbenzene sulphonate and 1- } \\
\text { butyl-3-methylimidazolium chloride. }\end{array}$ & $\mathrm{Cr}(\mathrm{IV})$ ions & [24] \\
\hline Acidic treatment & Aqueous tannic acid solution & $\mathrm{Pb}$ ions & [43] \\
\hline Alkaline treatment & $\begin{array}{l}\text { Sodium bisulphite }\left(\mathrm{NaHSO}_{3}\right) \text {, urea, and sodium } \\
\text { dodecyl sulphate ( } \mathrm{SDS}\end{array}$ & $\begin{array}{l}\text { Analytical grade } \\
\text { methylene blue }\end{array}$ & [44] \\
\hline Acidic treatment & $\begin{array}{l}\text { Aqueous acetic acid and sodium bicarbonate } \\
\left(\mathrm{NaHCO}_{3}\right)\end{array}$ & $\mathrm{Cu}$ ions & [45] \\
\hline $\begin{array}{l}\text { Acidic and alkaline } \\
\text { treatment }\end{array}$ & $\begin{array}{l}\text { hydrochloric acid, sodium bisulphite solution } \\
\text { and sodium hydroxide solution. }\end{array}$ & Acid blue-A dye & [46] \\
\hline
\end{tabular}

\section{Application of Chicken Feather}

The unique morphological structure of chicken feather enhances its interesting properties to be a low-cost adsorbent for different applications purposes. For instance, the chicken feather is used to remove the heavy metals ions, 
petroleum hydrocarbons, dye treatment and act as a hydrogen storage. Besides, the keratin contained in the chicken feather plays important role in converting it to added-value products such as animal feed supplement.

\subsection{Heavy Metal Removal}

Chemically treated chicken feathers are studied and used widely in the treatment of wastewater which contains the polluting metals from industrial water such as copper, zinc, calcium, magnesium, iron, manganese, lead, cadmium and nickel which are shown in Table 5. Results had shown that chicken feather is found convincing to act as a low-cost and environmentally friendly sorbent for the heavy metal removal. The examples of heavy metals and their operating factors in the batch adsorption studies are shown in Table 5. Based on Table 5, it shows that the concentration of heavy metal, the mass of chicken feather, the $\mathrm{pH}$ value and the temperature are the common influential factors for the removal efficiency of heavy metal.

Table 5 - Examples of heavy metals and their operating factors in the batch adsorption studies

\begin{tabular}{|c|c|c|c|c|c|c|c|c|c|}
\hline $\begin{array}{l}\text { Heavy } \\
\text { Metal }\end{array}$ & $\begin{array}{l}\text { Preparation of } \\
\text { Metal Solution }\end{array}$ & $\begin{array}{c}\text { Vol. of } \\
\text { Sample } \\
\text { (ml) }\end{array}$ & $\begin{array}{c}\text { Conc. of } \\
\text { Heavy } \\
\text { Metal } \\
(\mathrm{mg} / \mathrm{L}) \\
\end{array}$ & $\begin{array}{c}\text { Mass of } \\
\text { CF (g) }\end{array}$ & pH & $\begin{array}{c}\text { Solution for } \\
\text { Adjusting } \\
\text { pH }\end{array}$ & $\begin{array}{l}\text { Temp. } \\
\left({ }^{\circ} \mathbf{C}\right)\end{array}$ & $\begin{array}{l}\text { Shaking } \\
\text { Speed } \\
\text { (rpm) }\end{array}$ & Ref \\
\hline $\mathrm{Cu}$ & $\mathrm{CuSO}_{2} .5 \mathrm{H}_{2} \mathrm{O}$ & 50 & $10-50$ & 0.25 & - & - & - & - & [22] \\
\hline $\mathrm{Zn}$ & $\mathrm{ZnSO}_{4} .7 \mathrm{H}_{2} \mathrm{O}$ & & $20-100$ & & & & & & \\
\hline $\mathrm{Ca}$ & $\mathrm{CaCl}_{2}$ & 100 & $50-1000$ & $0.2-1.5$ & $2-9.5$ & - & $20-55$ & 150 & [21] \\
\hline $\mathrm{Mg}$ & $\mathrm{MgCl}_{2} \cdot 6 \mathrm{H}_{2} \mathrm{O}$ & & & & & & & & \\
\hline $\mathrm{Fe}$ & $\mathrm{FeCl}_{2} \cdot 4 \mathrm{H}_{2} \mathrm{O}$ & & & & & & & & \\
\hline Mn & $\mathrm{MnCl}_{2} .4 \mathrm{H}_{2} \mathrm{O}$ & & & & & & & & \\
\hline $\mathrm{Pb}$ & $\mathrm{Pb}\left(\mathrm{NO}_{3}\right)_{2}$ & 15 & $10-200$ & 0.06 & $2-5$ & $\begin{array}{l}\text { Diluted acid } \\
\text { solution }\end{array}$ & $25-40$ & 210 & [20] \\
\hline $\mathrm{Zn}^{2+}$ & $\begin{array}{c}\text { Nitrate salt, } \\
\mathrm{Zn}\left(\mathrm{NO}_{3}\right)_{2} \cdot 6 \mathrm{H}_{2} \mathrm{O}\end{array}$ & 15 & $1-100$ & 0.06 & $3-5$ & $\begin{array}{l}\text { Diluted } \\
\mathrm{NHO}_{3}\end{array}$ & $\begin{array}{c}25,30,4 \\
0\end{array}$ & - & [5] \\
\hline $\mathrm{Pb}$ & $\mathrm{Pb}\left(\mathrm{NO}_{3}\right)_{2}$ & 100 & 5 & 0.3 & $4-8$ & $\begin{array}{c}0.1 \mathrm{~N} \mathrm{HCl}, \\
\mathrm{NaOH}\end{array}$ & - & - & {$[2]$} \\
\hline $\begin{array}{l}\mathrm{Cd}^{2+} \\
\mathrm{Ni}^{2+}\end{array}$ & Nitrate salts & 15 & $10-200$ & 0.06 & $2-5$ & $\begin{array}{c}\text { Diluted } \\
\mathrm{HNO}_{3}\end{array}$ & $\begin{array}{c}25,30,4 \\
0 \\
\end{array}$ & - & [47] \\
\hline
\end{tabular}

\subsection{Petroleum Hydrocarbons Sorbent}

The oil industry is a sector that has given residence to a large contamination of hydrocarbons. Chicken feather has been studied to be used as a spill clean-up sorbent. The removal of petroleum hydrocarbons is studied in the keratinolytic mixed culture which is a system containing keratinous chicken feathers at different concentrations of petroleum hydrocarbons [31]. The removal is affected by the petroleum holding capacity of CF and the results are shown in Fig. 6.

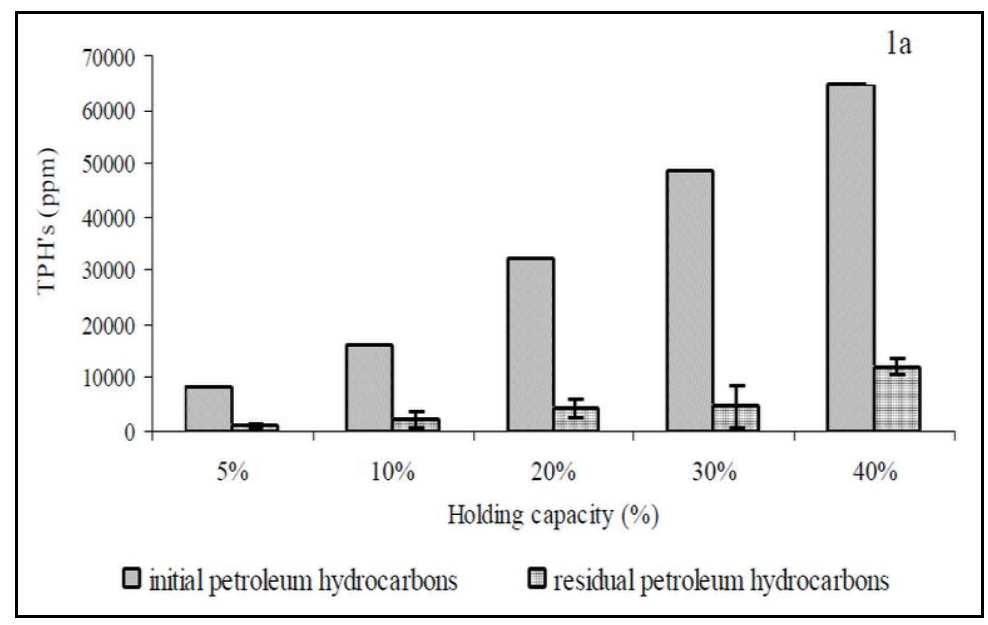

Fig. 6 - Petroleum hydrocarbons removal using chicken feather as sorbent by keratinolytic mixed culture [31] 


\subsection{Animal Feed}

Chicken feather keratin can also be used as an animal feed supplement [32]. Lime is found to be a potential agent in the treatment and solubilization of chicken feather protein. In the study that had been carried out by Coward-Kelly and his co-workers, lime (calcium hydroxide) was applied in the treatment of chicken feather keratin to obtain a liquid product that rich in polypeptides and amino acids. Results indicate that soluble hydrolyzed chicken feather keratin could be the main protein source for ruminants.

The production of feather meal by heat processing has been demonstrated by King'ori [33]. The heat treatment process from $115{ }^{\circ} \mathrm{C}$ to $145{ }^{\circ} \mathrm{C}$ makes the feather meal safe for animal feeds for a wide range of animal species, including fish and shrimp. The product after the heat treatment is an aseptic protein product which is free of the potential biohazards and the environmental threats [33].

\subsection{Dye Treatment}

Mittal had studied a lot in dye removal in his journeys [3], [34], [35], [37]. Table 6 shows the constants and operating factors chosen in the kinetic studies.

The dye that was considered is Malachite Green, a water-soluble dye which belongs to triphenylmethane family [34]. It is widely applied to dye cotton, leather, silk, wool and others. In addition, Mittal [35] also successfully removed Brilliant Blue FCF, a hazardous water-soluble triphenylmethane dye from wastewater by using the treated chicken feather. In the batch studies, the results significantly indicate that approximately $70 \%$ to $100 \%$ removal of dye $\left(1 \times 10^{-5}\right.$ $\left.-1 \times 10^{-4} \mathrm{M}\right)$ was obtained by hen feathers. Accordingly, a well-fitted linear relationship was obtained for the Freundlich and Langmuir adsorption isotherm models, suggesting an endothermic, spontaneous and feasible adsorption.

Later in 2007, the ability of chicken feather to remove Tartrazine and Indigo Carmine from aqueous solutions also has been studied. Last but not least, Chen et al. [38] investigate the removal of acid blue-A dye by using the chicken feathers as adsorbent and the results shown that the chicken feathers can be efficiently used to remove hazardous dye without detrimental to the water quality. Overall, feathers could be used as a valuable, effectual and economical adsorbent in the adsorption.

Table 6 - Constants and operating factors in kinetic studies in removal of dyes

\begin{tabular}{ccccccc}
\hline Dye & $\begin{array}{c}\text { Vol. } \\
(\mathbf{m l})\end{array}$ & $\begin{array}{c}\text { Conc. of Dye } \\
(\mathbf{M})\end{array}$ & $\begin{array}{c}\text { Mass of CF } \\
(\mathbf{g})\end{array}$ & pH & Temp $\left({ }^{\circ} \mathbf{C}\right)$ & Ref. \\
\hline Malachite Green & 25 & $1-10 \times 10^{-5}$ & $0.01-0.2$ & $3-7$ & $30,40,50$ & {$[34]$} \\
Brilliant Blue FCF & 25 & $1-10 \times 10^{-5}$ & $0.01-0.2$ & $2-6$ & $30,40,50$ & {$[35]$} \\
Tartrazine & 25 & $1-10 \times 10^{-5}$ & $0.005-0.025$ & $2-6$ & $30,40,50$ & {$[3]$} \\
Indigo Carmine & 25 & $1-10 \times 10^{-4}$ & $0.005-0.05$ & $2-6$ & $30,40,50$ & {$[37]$} \\
\hline
\end{tabular}

\subsection{Hydrogen Storage}

Pyrolyzed chicken feather fibers which are known as PCFF were prepared by a two-step pyrolysis process. From the work done by Senoz and Wool [4], the PCFF revealed a high $\mathrm{H}_{2}$ adsorption uptake owing to the nature of micropores. The PCFF exhibited a significant $\mathrm{H}_{2}$ adsorption affinity under the experimental condition with low pressure and temperature of $77 \mathrm{~K}$. According to the $\mathrm{H}_{2}$ adsorption analysis, the findings showed that two kinds of adsorption sites, which is micropores in the fibers and pores accessible to the $\mathrm{H}_{2}$ molecules, are available on the surface pyrolyzed chicken feather fibers

\section{Future Perspectives}

The development of low-cost adsorbent boosts the bright future of the adsorption process. Chicken feather is widely available as the poultry waste and shows its excellent performance as a low-cost adsorbent. Although there are many studies on the applications of the chicken feather, the chicken feather is still not being used in a large scale as an adsorbent. This may be due to the gap in the knowledge about the extensive utilization of the chicken feather as well as the management of the exhausted chicken feathers. As discussed in this review paper, the previous studies mostly employed this adsorbent for heavy metals removal by chemical activation. The potential of the chicken feather by the heating treatment or known as pyrolysis needs to be investigated and explored in detail. Furthermore, the morphological structures and properties of the chicken feather also enable it to go beyond the adsorbent's role. The fibers and protein in chicken feathers will be playing the important roles in converting the chicken feathers into valueadded products. Further studies on the chicken feather will be completed in future.

\section{Conclusion}

Literature shows that chicken feather which is the waste by-product from the poultry farming is the potential lowcost adsorbent. Many studies had done to evaluate the capabilities of the chicken feather as an adsorbent with different 
preparation methods. The development of chicken feather as a low-cost adsorbent brings a great solution on the environmental problems and waste management. From the critical evaluation of this review paper, it shows that the unique structure and interesting properties of the chicken feather make it as a potential low-cost adsorbent which is having a wide range of advantages and applications.

\section{Acknowledgement}

The authors acknowledge the financial support funded by Universiti Sains Malaysia Short Term Grant (Grant no. 304/PAWAM/60313009) and Intensive Grant (Grant no. 304/JPNP/600004).

\section{References}

[1] Wang, X., Guo, Y., Yang, L., Han, M., Zhao, J. and Cheng, X. (2012). Nanomaterials as sorbents to remove heavy metal ions in wastewater treatment. Journal of Environmental and Analytical Toxicology, 2, 1-7.

[2] Dunphy, M. P., Kumari, A. R., Babu, U. K. and Sobha, K. (2011). Optimization of lead adsorption using animal biopolymers by factorial design. International Journal of Science Innovations and Discoveries, 1, 303-319.

[3] Mittal, A., Kurup, L. and Mittal, J. (2007). Freundlich and Langmuir adsorption isotherms and kinetics for the removal of Tartrazine from aqueous solutions using hen feathers. Journal of Hazardous Materials, 146, $243-248$.

[4] Senoz, E. and Wool, R. P. (2011). Hydrogen storage on pyrolyzed chicken feather fibers. International Journal of Hydrogen Energy, 36, 7122-7127.

[5] Aguayo-Villarreal, I. A., Bonilla-Petriciolet, A., Hernández-Montoya, V., Montes-Morán, M. A. and Reynel-Avila, H. E. (2011). Batch and column studies of $\mathrm{Zn}^{2+}$ removal from aqueous solution using chicken feathers as sorbents. Chemical Engineering Journal, 167, 67-76.

[6] Ali, I., Asim, M. and Khan, T. A. (2012). Low cost adsorbents for the removal of organic pollutants from wastewater. Journal of Environmental Management, 113, 170-183.

[7] Yang, R. T. (2003). Adsorbents: Fundamentals and applications. Hoboken: John Wiley and Sons.

[8] Wang, X., Pei, Y., Lu, M., Lu, X. and Du, X. (2015). Highly efficient adsorption of heavy metals from wastewaters by graphene oxide-ordered mesoporous silica materials. Journal of Materials Science, 50, $2113-2121$.

[9] Djilani, C., Zaghdoudi, R., Djazi, F., Bouchekima, B., Lallam, A., Modarressi, A. and Rogalski, M. (2015). Adsorption of dyes on activated carbon prepared from apricot stones and commercial activated carbon. Journal of the Taiwan Institute of Chemical Engineers, 53, 112-121.

[10] Ruggieri, F., D'Archivio, A. A., Di Camillo, D., Lozzi, L., Maggi, M. A., Mercorio, R. and Santucci, S. (2015). Development of molecularly imprinted polymeric nanofibers by electrospinning and applications to pesticide adsorption. Journal of Separation Science, 38, 1402-1410.

[11] Kim, H., Hwang, Y. S. and Sharma, V. K. (2014). Adsorption of antibiotics and iopromide onto single-walled and multi-walled carbon nanotubes. Chemical Engineering Journal, 255, 23-27.

[12] Wu, F. C., Tseng, R. L. and Juang, R. S. (2005). Comparisons of porous and adsorption properties of carbons activated by steam and $\mathrm{KOH}$. Journal of Colloid and Interface Science, 283, 49-56.

[13] Eddy, M., Tchobanoglou, G. and Burton, F. L. (1991). Wastewater engineering: Treatment, disposal, and reuse. New York: McGraw-Hill

[14] Patterson, P. M., Cerofolini, G. F. and Re, N. (1993). The mathematical theory of adsorption on non-ideal surfaces. La Rivista Del Nuovo Cimento, 16, 1-63.

[15] Cornelissen, G., van Noort, P. C., Parsons, J. R. and Govers, H. A. (1997). Temperature dependence of slow adsorption and desorption kinetics of organic compounds in sediments. Environmental Science and Technology, 31, 454-460.

[16] Limousin, G., Gaudet, J. P., Charlet, L., Szenknect, S., Barthes, V. and Krimissa, M. (2007). Sorption isotherms: A review on physical bases, modeling and measurement. Applied Geochemistry, 22, 249-275.

[17] Mall, I. D., Srivastava, V. C., Agarwal, N. K. and Mishra, I. M. (2005). Removal of congo red from aqueous solution by bagasse fly ash and activated carbon: kinetic study and equilibrium isotherm analyses. Chemosphere, 61, 492-501.

[18] Agyei, N., Strydom, C. and Potgieter, J. (2000). An investigation of phosphate ion adsorption from aqueous solution by fly ash and slag. Cement and Concrete Research, 30, 823-826.

[19] Muherei, M. A. and Junin, R. (2009). Equilibrium adsorption isotherms of anionic, nonionic surfactants and their mixtures to shale and sandstone. Modern Applied Science, 3, 158-167.

[20] de la Rosa, G., Reynel-Avila, H. E., Bonilla-Petriciolet, A., Cano-Rodriguez, I., Velasco-Santos, C. and MartínezHernández, A. L. (2008). Recycling poultry feathers for Pb removal from wastewater: kinetic and equilibrium studies. Proceedings of World Academy of Science, Engineering and Technology, pp 1011-1019.

[21] Sayed, S., Saleh, S. and Hasan, E. (2005). Removal of some polluting metals from industrial water using chicken feathers. Desalination, 181, 243-255. 
[22] Al-Asheh, S., Banat, F. and Al-Rousan, D. (2003). Beneficial reuse of chicken feathers in removal of heavy metals from wastewater. Journal of Cleaner Production,11, 321-326.

[23]Fan, X. (2008). Value-added products from chicken feather fiber and protein, PhD Dissertation. Auburn University.

[24] Sun, P., Liu, Z. T. and Liu, Z. W. (2009). Particles from bird feather: A novel application of an ionic liquid and waste resource. Journal of Hazardous Materials, 170, 786-790.

[25] Cheung, H. Y., Ho, M. P., Lau, K. T., Cardona, F. and Hui, D. (2009). Natural fibre-reinforced composites for bioengineering and environmental engineering applications. Composites Part B: Engineering, 40, 655-663.

[26] Reddy, N. and Yang, Y. (2007). Structure and properties of chicken feather barbs as natural protein fibers. Journal of Polymers and the Environment, 15, 81-87.

[27] Senoz, E. and Wool, R. P. (2010). Microporous carbon-nitrogen fibers from keratin fibers by pyrolysis. Journal of Applied Polymer Science, 118, 1752-1765.

[28] Butler, M. and Johnson, A. S. (2004). Are melanized feather barbs stronger? Journal of Experimental Biology, 207, 285-293.

[29] Gibson, L. J. (2005). Biomechanics of cellular solids. Journal of Biomechanics, 38, 377-399.

[30] Kardaś, D., Kluska, J., Szuszkiewicz, J. and Szumowski, M. (2015). Experimental study of thermal pyrolysis of turkey feathers. Technical Sciences, 18(2), 115-124.

[31] Cervantes-Gonzalez, E., Rojas-Avelizapa, L. I., Cruzcamarillo, R., Garcia-Mena, J. and Rojas-Avelizapa, N. G. (2008). Feather waste as petroleum sorbent: a study of its structural biodegradation. Proceedings of the Annual International Conference on Soils Sediments, Water and Energy, 13, 50-58.

[32] Coward-Kelly, G., Chang, V. S., Agbogbo, F. K. and Holtzapple, M. T. (2006). Lime treatment of keratinous materials for the generation of highly digestible animal feed: 1. Chicken feathers. Bioresource Technology, 97, 1337-1343.

[33] King'ori, A. (2012). Management of poultry processing by-products - utilization of feathers. International Journal of Livestock Research, 2, 58-64.

[34] Mittal, A. (2006). Adsorption kinetics of removal of a toxic dye, Malachite Green, from wastewater by using hen feathers. Journal of Hazardous Materials, 133, 196-202.

[35] Mittal, A. (2006). Use of hen feathers as potential adsorbent for the removal of a hazardous dye, Brilliant Blue FCF, from wastewater. Journal of Hazardous Materials, 128, 233-239.

[36] Atkins, P. and De Paula, J. (2011). Physical chemistry for the life sciences. Oxford University Press,

[37] Mittal, A., Mittal, J. and Kurup, L. (2007). Utilization of hen feathers for the adsorption of indigo carmine from simulated effluents. Journal of Environmental Protection, 1, 92-100.

[38] Chen, B., Yan, L., Liu, X. and Worral, J. L. (2016). Poultry keratin based decolorants for dyeing wastewater treatment. Journal of Bioresources and Bioproducts, 1, 30-35.

[39] Kar, P. and Misra, M. (2004). Use of keratin fiber for separation of heavy metals from water. Journal of Chemical Technology and Biotechnology, 79, 1313-1319.

[40] Ping, S., Liu, Z. and Liu, Z. (2009). Chemically modified chicken feather as sorbent for removing toxic chromium (VI) Ions. Industrial and Engineering Chemistry Research, 48, 6882-6889.

[41] Sun, P., Liu, Z. T. and Liu, Z. W. (2009). Chemically modified chicken feather as sorbent for removing toxic chromium (VI) ions. Industrial and Engineering Chemistry Research, 48, 6882-6889.

[42] Saucedo-Rivalcoba, V., Martínez-Hernández, A. L., Martínez-Barrera, G., Velasco-Santos, C., Rivera-Armenta, J.L. and Castaño, V. M. (2011). Removal of hexavalent chromium from water by polyurethane-keratin hybrid membranes. Water, Air and Soil Pollution, 218, 557-571.

[43] Kumari, A. R., Babu, U. K. and Sobha, K. (2011). Optimization of lead adsorption using animal biopolymers by factorial design. International Journal of Science Innovations and Discoveries, 1, 303-319.

[44] Gao, P., Li, K., Liu, Z., Liu, B., Ma, C., Xue, G. and Zhou, M. (2014), Feather Keratin deposits as biosorbent for the removal of Methylene Blue from aqueous solution: Equilibrium, kinetics, and thermodynamics studies. Water, Air and Soil Pollution, 225, 1-13.

[45] Kumari, A. R. and Sobha, K. (2015). Cost effective and eco-friendly method for copper removal by adsorption with Emu feather (Dromaius novaehollandiae) and Chitosan (Agaricus bisporus) Composite. International Journal of ChemTech Research, 8, 1769-1782.

[46] Chen, B., Yan, L., Liu, X., and Worral, J. L. (2016), Poultry keratin based decolorants for dyeing wastewater treatment. Journal of Bioresources and Bioproducts, 1, 30-35.

[47] Reynel-Avilaa, H., Bonilla-Petriciolet, A. and de la Rosa, G. (2009). Removal of Cd (II) in aqueous solutions by chicken feathers, Proceeding of the 8th World Congress of Chemical Engineering, Montréal, Canada. 